REGARDS

SUR L'ECONOMIE ALLEMANDE

BULLETIN ECONOMIQUE DU CIRAC

\section{Regards sur l'économie allemande}

Bulletin économique du CIRAC

$66 \mid 2004$

Varia

\title{
Culture et transformation
}

EGER Thomas (ed), Kulturelle Prägungen wirtschaftlicher Institutionen und wirtschaftspolitischer Reformen

\section{(2) OpenEdition}

Journals

Édition électronique

URL : http://journals.openedition.org/rea/3873

DOI : $10.4000 /$ rea.3873

ISBN : 978-2-8218-0828-7

ISSN : 1965-0787

Éditeur

CIRAC

Édition imprimée

Date de publication : 1 mai 2004

ISSN : 1156-8992

Référence électronique

"Culture et transformation », Regards sur l'économie allemande [En ligne], 66 | mai 2004, mis en ligne le 13 octobre 2009, consulté le 21 septembre 2020. URL : http://journals.openedition.org/rea/3873 ; DOI : https://doi.org/10.4000/rea.3873

Ce document a été généré automatiquement le 21 septembre 2020

(C) CIRAC 


\section{Culture et transformation}

EGER Thomas (ed), Kulturelle Prägungen wirtschaftlicher Institutionen und wirtschaftspolitischer Reformen

\section{RÉFÉRENCE}

EGER Thomas (ed), Kulturelle Prägungen wirtschaftlicher Institutionen und

wirtschaftspolitischer Reformen, Schriften des Vereins für Socialpolitik, vol. 291,

Duncker \& Humblot, Berlin, 2002, 214 p.

1 Comment expliquer la grande disparité des processus de transformation? La performante Pologne n'a guère privatisé son économie. La Russie, ultra-libérale en comparaison, affronte de graves difficultés. Quant au 'miracle' chinois... La réponse : les cultures et leurs évolutions, auxquelles sont consacrés ces actes d'un colloque sur l'empreinte culturelle des institutions et politiques économiques organisé en 2001 à Leipzig par la Société scientifique des chercheurs en économie et sciences sociales de langue allemande. (IB) 